Covered in: ERIH PLUS, HeinOnline, CEEOL, Index Copernicus, CrossRef, CrossCheck, J-GATE, Google Scholar, Ideas RePeC, Econpapers, Socionet, KVK, WorldCat.

\section{Review of the} volume

„Competența judecătorului de

\section{cameră}

\section{preliminară”,} authored by Denisa Barbu and Georgiana Marina Niculae, published by LUMEN Publishing House, 2019

[Recenzie la volumul „Competența judecătorului de cameră preliminară", autori: Denisa Barbu şi Georgiana Marina Niculae, publicat la editura LUMEN, Iaşi, 2019]

\section{Alexandra HUIDU1}

${ }^{1} \mathrm{PhD}$ Student, LUMEN Research Center in Social and Humanistic Sciences, Iasi, Romania; Doctoral School of Sociology, University of Oradea, Romania, andra_huidu@yahoo.com
Abstract: The volume „The competence of the Preliminary Chamber Judge", written by Denisa Barbu and Georgiana Marina Niculae and published by Lumen Publishing House, Iasi, 2019, is a book in one of the most important and better outlined branches of law, criminal procedural law, and which enters, as a format and subject, in any collection of legal books that wants to present the basics of law, the present volume being recommended by the quality of the research. The volume discusses the institution of the preliminary chamber judge monographically, being both a theoretical analysis and a critique of solutions in judicial practice and an analysis for the future, de lege ferenda.

Keywords: court jurisdiction; preliminary chamber; criminal trial; Denisa Barbu, Georgiana Marina Niculae.

How to cite: Huidu, A. (2019). Review of the volume „Competența judecătorului de cameră preliminară”, authored by Denisa Barbu and Georgiana Marina Niculae, published by LUMEN Publishing House, 2019. Logos Universality Mentality Education Novelty: Law, 7(1), 85-88. doi:10.18662/lumenlaw/21 
Review of the volume "Competenta judecatorului de camera preliminara", ... Alexandra HUIDU

Orice lucrare de drept procesual penal este incontestabil o lucrare utilă, care se adresează tuturor juriştilor, teoreticieni, practicieni, studenți etc. Dar nu orice lucrare care vizează instituțiile de bază ale procesului penal este în acelaşi timp şi meritorie. În cazul lucrării „Competența judecătorului de cameră preliminară" (Barbu \& Niculae, 2019), remarcăm îndeplinirea acestei din urmă condiții. Fireşte că faţă de tema abordată şi noutatea acestei instituții, a judecătorului de cameră preliminară, în dreptul românesc, cartea s-ar încadra mai degrabă în categoria instrumentelor de lucru pentru practicieni şi a instrumentelor de informare pentru cei care doresc să acceadă în profesiile juridice. Modul didactic de scriere se îmbină cu stilul înalt academic, noțiunile fundamentale sunt explicate pentru uzul tuturor juriştilor, dar sunt completate cu teorii şi discuții de doctrină de o complexitate ridicată. Lucrarea este elaborată cu grijă, conține toate elementele discuțiilor de specialitate în domeniu, aduce în plus punctele de vedere valoroase ale autorilor şi convinge prin rigurozitate şi asumarea unui demers ştiințific deloc facil, dus la bun sfârşit într-o manieră meritorie.

Autoarea Denisa Barbu demonstrează în acest volum talentul său de cadru didactic în cadrul Facultăţii de Drept şi Ştiințe Administrative a Universității Valaia din Târgovişte, dar mai ales faptul că este un scriitor experimentat de doctrină juridică, sens în care amintim cele cinci volume publicate anterior tot sub egida Editurii Lumen: Genocidul, infractiunile contra umanității și cele de răsboi. Repere in Codul penal român în raport cu Statutul de la Roma (Barbu, 2015a), Răspunderea persoanei fiæice in dreptul international penal (Barbu, 2015b), Principiile procesului penal (Barbu, 2015c), Drept procesual penal. Partea generală (Barbu, 2016), Drept procesual penal. Partea generală. Caiet de seminar (Barbu \& Petrea, 2016). Iar acum Denisa Barbu „recidivează”, însă nu singură, ci , în coautorat”, ba chiar ca şi ,instigator moral” al debutului în domeniul doctrinei juridice a coautoarei sale, Georgiana Marina Niculae.

Observăm că autoarele reuşesc cu succes să evite prezentarea exhaustivă a anumitor problematici în dauna altora, şi se axează pe abordarea temelor de o manieră echilibrată, care să acorde acces cât mai vast la informaţie şi puncte de plecare pentru cercetări viitoare. Pe cale de consecință, apreciem că autoarele mențin pe tot parcursul lucrării echilibrul necesar între subiectele tratate, aspectele teoretice şi cele practice şi a importanței acordate în economia generală a demersului şiinţific fiecăruia dintre aceste alemente, chiar dacă uneori autoarele aleg o manieră accentuat didactică de prezentare.

Din lecturarea tablei de materii, se va observa cu uşurință faptul că nu se omite niciun capitol sau subcapitol care ar face completă o astfel de lucrare. Modul de tratare a tuturor subiectelor enumerate în tabla de materii 
este cel clasic, care combină elemente didactice, pentru uzul şi înţelesul studenților, cu noțiuni avansate de doctrină şi teorie juridică, cu practică judiciară relevantă în materie, valorificând numeroase surse externe. Autoarele achiesează la unele opinii, le critică argumentat pe altele, îşi formulează propriile puncte de vedere, astfel cum se aşteaptă de la orice lucrare cu o astfel de temă de cercetare. Fiecare subiect este tratat în mod organizat, complet şi bine structurat, acordându-i-se relevanța pe care o are în teoria generală a dreptului procesual penal, în vederea atingerii scopului lucrării: punctarea elementelor obligatorii, acordarea explicaţiilor necesare, argumentarea controverselor teoretice, inserarea exemplelor practice.

Pe alocuri este evident că lucrarea se adresează studenţilor şi se doreşte a fi un instrument de lucru la catedră, ceea ce face ca accentul să cadă în volum asupra chestiunilor care ar interesa un jurist începător. Față de acest aspect, deşi uneori cercetarea ar putea fi aprofundată şi elaborată mai extins, este evident că nu acesta a fost scopul autoarelor, cu atât mai mult cu cât instituția de drept căreia îi este dedicată monografia nu are o tradiție prea îndelungată în dreptul românesc şi se simte în egală măsură necesitatea unei stabilizări, în primul rând la nivel teoretic, pentru ca ulterior aceasta să atargă după sine stabilizarea aspectelor controversate sau discutabile din practica instanțelor de judecată. Mai mult, demersul didactic este condus cu talent şi îşi atinge scopul, datorită limbajului clar, a modului complet în care sunt prezentate noțiunile de bază şi a stilului curat de redactare a lucrării.

Asumarea unei lucrări pe o astfel de temă nu este o sarcină uşoară pentru niciun autor de carte ştiințifică, întrucât presupune cunoştințe solide în materie, o documentare foarte şi sarcina deloc de neglijat de a corela surse de informare, noțiuni şi opinii de o varietate remarcabilă. Autoarele reuşesc să facă asta, aducând în fața cititorului o lucrare bine închegată, remarcabil organizată, echilibrată şi scrisă la un înalt nivel academic.

Cartea vizează, după cum am spus, un public extrem de larg. Pornind de la studenți, masteranzi, doctoranzi şi orice persoane care doresc să studieze materia dreptului procesual penal în vederea promovării examenelor de acces în branşele profesionale ale dreptului sau în magistratură, această carte se adresează în egală măsură practicienilor avocați, procurori şi judecători. Poate fi folosită ca un instrument de învăţare, un instrument de cercetare sau unul de informare, urmând a-şi atinge scopul şi a furniza cititorului răspunsurile căutate în orcare dintre aceste variante.

Efortul de selectare, lecturare, triere, valorificare a resurselor bibliografice se face remarcat din paginile cărții şi, în plus, numărul de decizii de speță care au fost aduse în atenția cititorului s-a limitat la indicarea celor relevante după o atentă triere, ceea ce este, de asemenea, un efort consistent 
şi meritoriu. Toate aceste elemente transformă volumul într-unul de certă valoare ştiințifică.

Bine structurată, foarte bine documentată, cu o scriitură de certă clasă ştiințifică, volumul poate sta alături de monografiile de gen din literatura de specialitate consecrate déjà în doctrina românească. Lucrarea de față se recomandă şi se impune de la sine, față de importanța temei, interesul extins care se manifestă în mediul juridic pentru temă, calitatea cercetării, profunzimea analizei ştiințifice, claritatea de prezentare sub aspect didactic şi informativ, eleganţa scriiturii, documentarea deosebită efectuată de autoare în vederea elaborării volumului şi impresia generală de calitate pe care cartea o lasă în final sub toate aspectele.

\section{Acknowledgement}

This paper was elaborated within the doctoral research entitled "Social and Bioethical Acceptance of Techniques Related to Medically Assisted Human Reproduction in Romania", within and with funding by the doctoral scholarship awarded by the Doctoral School of Sociology, University of Oradea, Romania. The research is carried out in cocoordination with the University of Medicine and Pharmacy Grigore T. Popa from Iasi, Romania.

\section{Bibliografie}

Barbu, D., \& Niculae, G. M. (2019). Competența judecătorului de cameră preliminară. Iaşi, România: Lumen.

Barbu, D. (2015a). Genocidul, infracţiunile contra umanitătiii și cele de răz̧boi. Repere in Codul penal român in raport cu Statutul de la Roma. Iaşi, România: Lumen.

Barbu, D. (2015b). Răspunderea persoanei fizice in dreptul internațional penal. Iaşi, România: Lumen.

Barbu, D. (2015c). Principiile procesului penal. Iaşi, România: Lumen.

Barbu, D. (2016). Drept procesual penal. Partea generală. Iaşi, România: Lumen.

Barbu, D, \& Petrea, A. (2016). Drept procesual penal. Partea generală. Caiet de seminar. Iaşi, România: Lumen. 